\title{
Production of renewable biofuels and chemicals by processing bio-feedstock in conventional petroleum refineries
}

\author{
Nghiên cứu khả năng tích hợp chế biến nguyên liệu sinh khối trong nhà máy lọc \\ dầu để sản xuất nhiên liệu sinh học và hóa phẩm cho hóa dầu
}

Research article

\author{
Vu, Xuan Hoan ${ }^{*}$; Nguyen, Sura ${ }^{1}$; Dang, Thanh Tung ${ }^{1}$; Armbruster, Udo ${ }^{2}$; Martin, Andreas ${ }^{2}$ \\ ${ }^{1}$ Vietnam Petroleum Institute, 173 Trung Kinh, Yen Hoa, Cau Giay, Hanoi, Vietnam; ${ }^{2}$ Leibniz Institute for Catalysis \\ e.V. at the University of Rostock, Albert-Einstein-Str.29a, 18059 Rostock, Germany
}

\begin{abstract}
The influence of catalyst characteristics, i.e., acidity and porosity on the product distribution in the cracking of triglyceride-rich biomass under fluid catalytic cracking (FCC) conditions is reported. It has found that the degradation degree of triglyceride molecules is strongly dependent on the catalysts' acidity. The higher density of acid sites enhances the conversion of triglycerides to lighter products such as gaseous products and gasoline-range hydrocarbons. The formation of gasolinerange aromatics and light olefins (propene and ethene) is favored in the medium pore channel of H-ZSM-5. On the other hand, heavier olefins such as gasoline-range and C4 olefins are formed preferentially in the large pore structure of zeolite Y based FCC catalyst (Midas-BSR). With both catalysts, triglyceride molecules are mainly converted to a mixture of hydrocarbons, which can be used as liquid fuels and platform chemicals. Hence, the utilization of the existing FCC units in conventional petroleum refineries for processing of triglyceride based feedstock, in particular waste cooking oil may open the way for production of renewable liquid fuels and chemicals in the near future.
\end{abstract}

\begin{abstract}
Bài báo trình bày kết quả nghiên cứu khả năng tích hợp sản xuất nhiên liệu sinh học và hóa phẩm tù̀ nguồn nguyên liệu tái tạo sinh khối giầu triglyceride bằng công nghệ cracking xúc tác tấng sôi (FCC) trong nhà máy lọc dầu. Kết quả nghiên cưu cho thấy xúc tác có ảnh hương mạn đến hiệu quả chuyển hóa triglyceride thành hydrocarbon. Tính acid của xúc tác càng mạnh thì độ chuyển hóa càng cao và thu được nhiều sản phẩm nhe hơn nhu xăng và các olefin nhẹ. Xúc tác vi mao quản trung bình nhu H-ZSM-5 có độ chọn lọc cao với hợp chất vòng thơm thuộc phân đoạn xăng và olefin nhe nhu propylen và ethylen. Với kích thuó́c vi mao quản lón, xúc tác công nghiẹp FCC dựa trên zeolite Y uu tiên hình thành C4 olefins và các olefin trong phân đoạn xăng. Ở điều kiện phản úng của quá trình FCC, triglyceride chuyển hóa hiệu quả thành hydrocarbon mà có thể sủ dụng làm xăng sinh học cho động co và olefin nhẹ làm nguyên liệu cho tổng hợp hóa dầu.
\end{abstract}

Keywords: biofuels, light olefins, waste cooking oil, catalytic cracking

\section{Introduction}

The depletion of petroleum resources along with environmental concerns has led to the search for renewable alternatives to alleviate our dependency on fossil fuels and to reduce green-house gas (mainly $\mathrm{CO}_{2}$ ) emissions. One promising route to yield renewable liquid fuels and chemicals is the conversion of triglyceride-rich biomass in conventional oil refineries (Al-Sabawi et al., 2012;
Huber et al., 2007; Melero et al., 2012). In this respect, the processing of such triglyceride mixtures in fluid catalytic cracking (FCC) units is the process of choice since it is the only process that enables to directly produce gasoline, middle distillates as transportation fuels and light olefins as platform chemicals. Moreover, the use of standard FCC units that are already built in petroleum refineries for transformation of triglyceride based feedstock would require little capital investment, which makes 
this process more economically attractive than other strategies (Melero et al., 2012).

Triglyceride-rich biomass includes animal fats and plant oils, more commonly known as vegetable oils, which contain mostly triglyceride molecules. The direct use of edible vegetable oils, e.g., rapeseed oil or palm oil for biofuel production might have negative impacts on the arable land culture and edible food supply (Taufiqurrahmi et al., 2011). Therefore, non-edible oils such as waste cooking oil (WCO) have been emerging as potential raw materials for producing biofuels and chemicals. Large quantities of WCO can be obtained from waste streams of various industries such as the food industry or animal waste rendering sources if a proper collection system is established. For instance, in EU countries, about 1 million t/a of WCO is generated whereas the estimated amount in the US is approximately 0.4 million t/a (Chhetri et al., 2008).

There is a rich body of literature on catalytic cracking of vegetable oils in which various aspects of cracking of triglycerides have been extensively studied (Al-Sabawi et al., 2012; Maher et al., 2007). It has been demonstrated that the catalytic cracking of triglycerides produced a mixture of hydrocarbons that can be used as liquid fuels and chemicals. Furthermore, the product distribution heavily relies on catalyst characteristics. For example, medium pore zeolites such as ZSM-5 showed higher selectivity toward gasoline-range hydrocarbons than large pore zeolites such as BEA or Y (Chen et al., 2010; Twaiq et al., 1999). However, most of these laboratory-scale works were performed in a fixed-bed microactivity (MAT) reactor with much longer contact times (20-75 s) compared to a commercial riser reactor (2-10 s). In other words, the experimental conditions employed for these studies are far from those of an industrial FCC unit. To date, the effect of catalyst characteristics on the product distribution in catalytic cracking of triglycerides under FCC conditions is poorly described in the literature.

In this work, in order to study such effect in the cracking of triglyceride-rich biomass under FCC conditions, we carried out the cracking of waste cooking oils as representative bio-feedstock over two different type zeolite based catalysts, i.e., industrial FCC catalyst (based on large pore zeolite Y) and H-ZSM-5 (medium pore zeolite) using a Short-Contact-Time Microactivity Test unit (SCT-MAT) from Grace Davison. The use of the SCTMAT unit allows avoiding most of the shortcomings encountered with the traditional fixed-bed microactivity test equipment, such as large contact time (20-70 s) or low temperatures in the preheating section (which might hamper an appropriate feed vaporization), and therefore simulating more accurately an industrial FCC unit.

\section{Materials and methods}

\subsection{Feedstock}

Waste cooking oil used as bio-feedstock for the catalytic cracking experiments was collected from a local restaurant. The fatty acid composition is shown in Table 1.

\section{Table 1. Fatty acid composition of WCO}

\begin{tabular}{lc} 
Fatty acid composition as wt\% methyl esters & \\
\hline Dodecanoic acid [C12:0] & 1.2 \\
Palmitic acid [C16:0] & 37.2 \\
Stearic acid [C18:0] & 4.9 \\
Oleic acid [C18:1] & 48.8 \\
Linoleic acid [C18:2] & 7.9 \\
\hline
\end{tabular}

[Cx:y] where $\mathrm{x}$ is the number of carbon atoms and $\mathrm{y}$ is the number of double bonds.

\subsection{Catalysts}

The industrial FCC catalyst (Midas-BSR, Grace Davison) and commercial H-ZSM-5 (Zeocat PZ-2/25, ZeoChem AG), which are widely used as catalysts and additives for FCC processes in petroleum refineries respectively, were employed to evaluate the influence of the catalyst characteristics on the production of the desirable products, i.e., gasoline and light olefins in the cracking of WCO under FCC conditions. The physico-chemical properties of these catalysts are given in Table 2 . To evaluate the effect of thermal cracking, an inert material (glass bead) was used.

\section{Table 2. Physico-chemical properties of FCC and H- ZSM-5 catalysts}

\begin{tabular}{lrr} 
Catalysts & Midas-BSR & H-ZSM-5 \\
\hline $\begin{array}{l}\text { Chemical composition } \\
\text { (wt\%) }\end{array}$ & & \\
$\mathrm{Al}_{2} \mathrm{O}_{3}$ & 44.17 & 6.21 \\
$\mathrm{SiO}_{2}$ & 52.91 & 92.28 \\
$\mathrm{Na}_{2} \mathrm{O}$ & 0.12 & 0.04 \\
Textural properties & & \\
BET surface, $\mathrm{m}^{2} / \mathrm{g}$ & 217 & 373 \\
Pore volume, $\mathrm{cm}^{3} / \mathrm{g}$ & 0.18 & 0.22 \\
Unit cell, nm & 0.2459 & $\mathrm{n} . \mathrm{a}$ \\
Total acidity, $m g \mathrm{NH}_{3} / \mathrm{g}$ & 0.64 & 1.24 \\
\hline
\end{tabular}

\subsection{Experimental set-up}

Catalytic cracking of WCO was performed on a fully automated Single Receiver Short-Contact-Time Microactivity Test (SCT-MAT) unit from Grace Davison. The experimental setup is presented in Figure 1 and consists of a feeding module (1), a metallic fixed bed tubular reactor (2) heated by a three-zone furnace (3) and a product collecting system (4). The feeding module is equipped with a heated syringe $\left(80{ }^{\circ} \mathrm{C}\right)$ and a special motor pump for injecting feedstock into the reactor. The tubular bed reactor (13 $\mathrm{mm}$ internal diameter) is filled with a fixed bed where the catalyst is diluted with inert glass beads to maintain a constant-volume reaction independent of the catalyst to oil mass ratio used. A specialized single receiver is used to collect the vapor and liquid products of cracking reactions. 


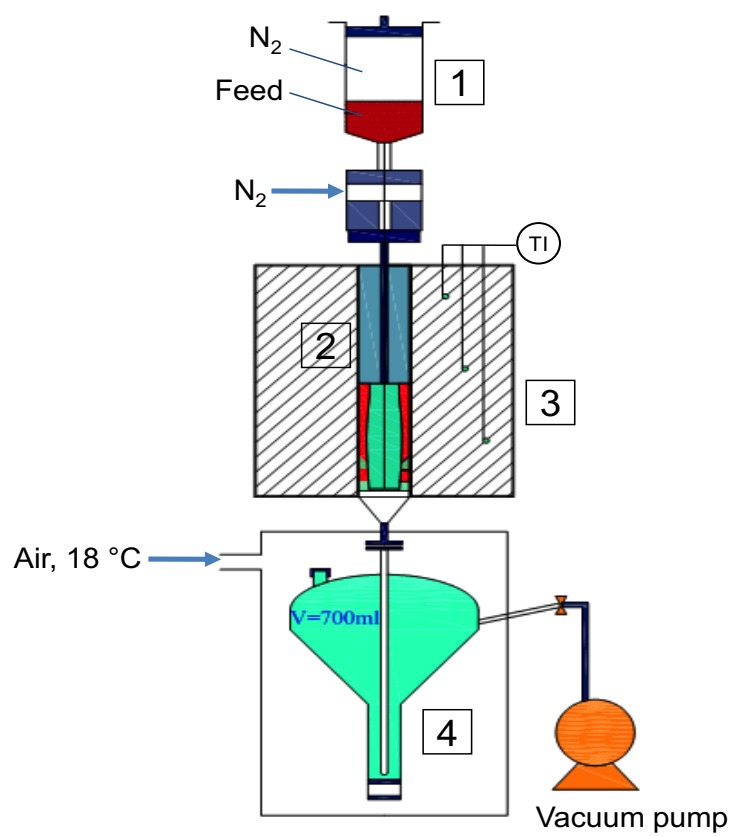

Figure 1. Experimental setup of the SCT-MAT unit

The catalytic cracking experiments of WCO were carried out at ambient pressure, $550{ }^{\circ} \mathrm{C}$ and a catalyst-to-oil (CTO) mass ratio of $0.4(\mathrm{~g} / \mathrm{g})$. In a typical run, $1.75 \mathrm{~g}$ of feedstock (WCO) was fed into the reactor which contained a desired amount of catalyst diluted with glass beads by the way mentioned above. The total injection time was $12 \mathrm{~s}$. After the reaction, stripping of catalyst was carried out by using a nitrogen purge. The gaseous and liquid products were collected in the single receiver cooled at $+18{ }^{\circ} \mathrm{C}$ via cooling system. The mass balance was between $95-100 \%$ of the injected feed in all runs.

\subsection{Cracking product analysis}

The cracking products comprised predominantly hydrocarbons along with oxygenated compounds (mainly water, $\mathrm{CO}$ and $\mathrm{CO}_{2}$ ) and coke. Due to the complexity of the cracking products obtained from a FCC unit, the main hydrocarbons are usually grouped in terms of lumps of boiling ranges. The gaseous hydrocarbon fraction is divided into dry gas (hydrogen, methane, ethane, and ethylene) and liquefied petroleum gas (LPG; propane, propene, butenes, and butanes). The liquid hydrocarbons are lumped in terms of boiling ranges: $\mathrm{C}_{5+}$ gasoline $(<211$ $\left.{ }^{\circ} \mathrm{C}\right)$, light cycle oil $\left(\mathrm{LCO} ; 221-360{ }^{\circ} \mathrm{C}\right)$ and heavy cycle oil $\left(\mathrm{HCO} ;>360^{\circ} \mathrm{C}\right)$.

The gaseous products were analyzed according to ASTM D1945-3 method using a Refinery Gas Analyzer (HP Agilent 7890 A, configured with three channels, including one FID and two TCD (thermal conductivity detector)). Light hydrocarbons $\left(\mathrm{C}_{1}-\mathrm{C}_{5}\right)$ were analyzed on the FID channel. One TCD with nitrogen carrier was employed to determine hydrogen because of the small difference in the conductivity of hydrogen and helium carrier. The other TCD with helium as carrier gas was used to detect $\mathrm{CO}$, $\mathrm{CO}_{2}, \mathrm{~N}_{2}$ and $\mathrm{O}_{2}$. For quantitative analysis, the response factor was determined by using a RGA (Refinery Gas
Analysis) calibration gas standard (National Oxygen Pte.).

The liquid organic products were classified according to boiling ranges: $\mathrm{C}_{5+}$ gasoline, $\mathrm{LCO}$ and $\mathrm{HCO}$ as mentioned above by means of simulated distillation (ASTM D2887) on a Simulated Distillation gas chromatograph (Agilent 7890 A, equipped with a capillary column (DB-2887, $10 \mathrm{mx} 0.53 \mathrm{~mm} \times 0.3 \mu \mathrm{m}$ ) and a FID). For calibration, a reference gas oil sample (RGO-2887, Agilent) was used. For several liquid samples, PIONA (Paraffin, i-Paraffin, Olefin, Naphthene, and Aromatic) analyses were performed to determine the composition of gasoline using a HP Agilent 7890 A equipped with Hydrocarbon Expert software from Separation System Inc. This method yields the hydrocarbon distribution in the form of n-paraffins, iparaffins, naphthenes, olefins, and aromatics in the gasoline boiling range (roughly up to $\mathrm{C}_{15}$ ). Water was measured by a Karl Fischer titration (MKS-520, Kem) and coke was determined by an elemental analyzer (CS600, Leco).

The yield toward different products $\left(\mathrm{Y}_{\mathrm{i}}, \mathrm{wt} \%\right)$ is defined as gram of product i per gram of the feed. The standard MAT conversion is defined as $100 \%-\left(\mathrm{Y}_{\mathrm{HCO}}+\mathrm{Y}_{\mathrm{LCO}}\right)$.

\section{Results and discussion}

\subsection{Thermal cracking}

Thermal cracking may provide the basis on which the contribution of catalytic properties can be assessed. To understand such effect, in the present study, the thermal cracking of $\mathrm{WCO}$ was carried out at $550^{\circ} \mathrm{C}$ over glass beads (inert material). The results are summarized in Table 3 .

It is evident that the thermal degradation of WCO took place considerably at $550{ }^{\circ} \mathrm{C}$, giving a conversion of 26.4 $\mathrm{wt} \%$. However, the yield of $\mathrm{HCO}$ is high; suggesting that most of heavy oxygenated compounds formed by the decomposition of triglycerides have not converted thermally, which is in line with the earlier reports (Dupain et al., 2007; Idem et al., 1996). Dupain et al. (2007) studied the thermal cracking of rapeseed oil in a micro-riser reactor with adjustable reaction time. The results showed that $72 \mathrm{wt} \%$ of triglycerides were already converted to fatty acids at $525{ }^{\circ} \mathrm{C}$ within $50 \mathrm{~ms}$. After approximately $5.8 \mathrm{~s}$, nearly complete conversion of triglycerides was achieved whereas the consecutive conversion of fatty acids remained relatively low, which gave a high yield (approximately $60 \mathrm{wt} \%$ ) of heavy oxygenated compounds (mainly fatty acids).

From Table 3, one can see that $\mathrm{CO}, \mathrm{CO}_{2}$ and light olefins, in particular ethene, are predominant in the gas composition. This suggests that decarbonylation and decarboxylation reactions as well as secondary cracking reactions, involving the elimination of ethylene from hydrocarbons, occur preferentially. However, the low yield of gaseous products accompanied by the large fraction of unconverted fatty acids evidences the poor selectivity of thermal cracking of triglycerides toward valuable fuel compounds. 
On the other hand, the effect of thermal cracking should be taken into account when evaluating the catalytic performance at high temperature since it might open a parallel degradation route.

Table 3. Thermal cracking of $\mathrm{WCO}$ at $550{ }^{\circ} \mathrm{C}$

\section{Conversion and product yield $(\mathrm{wt} \%)^{\mathrm{a}}$}

Conversion $(\mathrm{wt} \%)$
Product yields $(\mathrm{wt} \%)$
Total gas
Dry gas
LPG
Light olefins $\left(\mathrm{C}_{2}-\mathrm{C}_{4}\right)$
$\mathrm{CO}, \mathrm{CO}_{2}$
$\mathrm{C}_{5}$ gasoline
LCO
HCO
Coke
Water

\section{Gas composition (wt\%)}

\begin{tabular}{clc}
26.4 & Hydrogen & 0.44 \\
& Methane & 3.08 \\
7.9 & Ethane & 5.02 \\
1.6 & Ethene & 11.37 \\
2.1 & Propane & 4.57 \\
2.3 & Propene & 9.32 \\
4.2 & i-Butane & 0.02 \\
17.3 & n-Butane & 4.20 \\
29.0 & t-2-Butene & 0.45 \\
44.6 & 1-Butene & 7.23 \\
0.1 & i-Butene & 0.19 \\
1.2 & c-2-Butene & 0.30 \\
& CO 2 & 34.81 \\
& CO & 18.95 \\
\hline
\end{tabular}

\subsection{Catalytic cracking}

Catalytic cracking of triglyceride-based feedstock is generally initiated by thermal decomposition of triglyceride molecules into fatty acids by means of free radical mechanism. Then the acid zeolite based catalyst controls the process and converts the formed fatty acid into oxygenated products (mainly $\mathrm{CO}, \mathrm{CO}_{2}$ and water) and a mixture of hydrocarbons (Maher et al., 2007). It has been reported that the quality and yield of the desired products, i.e., gasoline-range hydrocarbons and light olefins are strongly dependent on the catalyst characteristics. To understand this phenomenon, in the present study, we carried out the cracking of WCO over two different type zeolite based catalysts (FCC catalyst and H-ZSM-5) under FCC conditions $\left(550{ }^{\circ} \mathrm{C}, \mathrm{CTO}\right.$ ratio $=0.4 \mathrm{~g} / \mathrm{g}$ and a contact time of $12 \mathrm{~s})$. The overall data on their catalytic performance are given in Table 4 and the gas and gasoline compositions are shown in Figures 2, 3 respectively.

As shown in Table 4, the industrial FCC catalyst (MidasBSR) exhibits a lower conversion of approximately 60 $\mathrm{wt} \%$, compared to the almost complete conversion over H-ZSM-5. It can be explained by the fact that Midas-BSR comprises a mixture of active zeolite phase $(<50 \mathrm{wt} \%)$ with other less active components such as amorphous silica-alumina serving as supports, which reduces the acid site density (Table 2), consequently its catalytic activity. On the contrary, H-ZSM-5 containing mainly crystalline ZSM-5 phase with higher acidity is far more active, giving a considerably higher conversion of $91.5 \mathrm{wt} \%$. This further supports the fact that most of secondary cracking reactions of triglycerides are catalysed by active acid sites of zeolites, in good agreement with the work of Chen et al. (2010) and Katikaneni et al. (1996).
Table 4: Catalytic performance of Midas-BSR and $\mathrm{H}-$ ZSM-5 in the catalytic cracking of WCO at $550{ }^{\circ} \mathrm{C}$, CTO ratio $=0.4 \mathrm{~g} / \mathrm{g}$

\begin{tabular}{lcc} 
Catalysts & FCC catalyst & H-ZSM-5 \\
\hline Conversion $\left(\mathrm{wt}^{\circ} \%\right)$ & 59.8 & 91.5 \\
Product yields $(\mathrm{wt} \%)$ & & \\
Total gas & 19.1 & 48.8 \\
Dry gas & 2.4 & 8.2 \\
$\mathrm{LPG}$ & 11.6 & 33.7 \\
Light olefins $\left(\mathrm{C}_{2}-\mathrm{C}_{4}\right)$ & 10.6 & 30.4 \\
$\mathrm{CO}, \mathrm{CO}_{2}$ & 5.1 & 6.9 \\
$\mathrm{C}_{5}$ gasoline & 34.4 & 35.0 \\
$\mathrm{LCO}$ & 18.2 & 4.0 \\
$\mathrm{HCO}$ & 22.0 & 4.5 \\
Coke & 2.3 & 1.2 \\
Water & 4.1 & 6.5 \\
\hline
\end{tabular}

$\mathrm{wt} \%$ on a feed basis

Regarding the product distribution, one can see from Table 4 that H-ZSM-5 displays significantly higher yields of desired products (in particular light olefins) and lower yields of undesired products such as HCO, LCO and coke than FCC catalyst. The superior catalytic performance of H-ZSM-5 to Midas-BSR may result from the advantageous combination of its higher acidity and shape selectivity. On the one hand the greater amount of acid sites of H-ZSM-5 has facilitated the conversion of heavy fractions, i.e., HCO and LCO to lighter and more valuable products, i.e., gasoline and light olefins, on the other hand the shape selectivity of the medium pore zeolite enables 
H-ZSM-5 to drive the cracking process toward the formation of light olefins (Katikaneni et al., 1996).

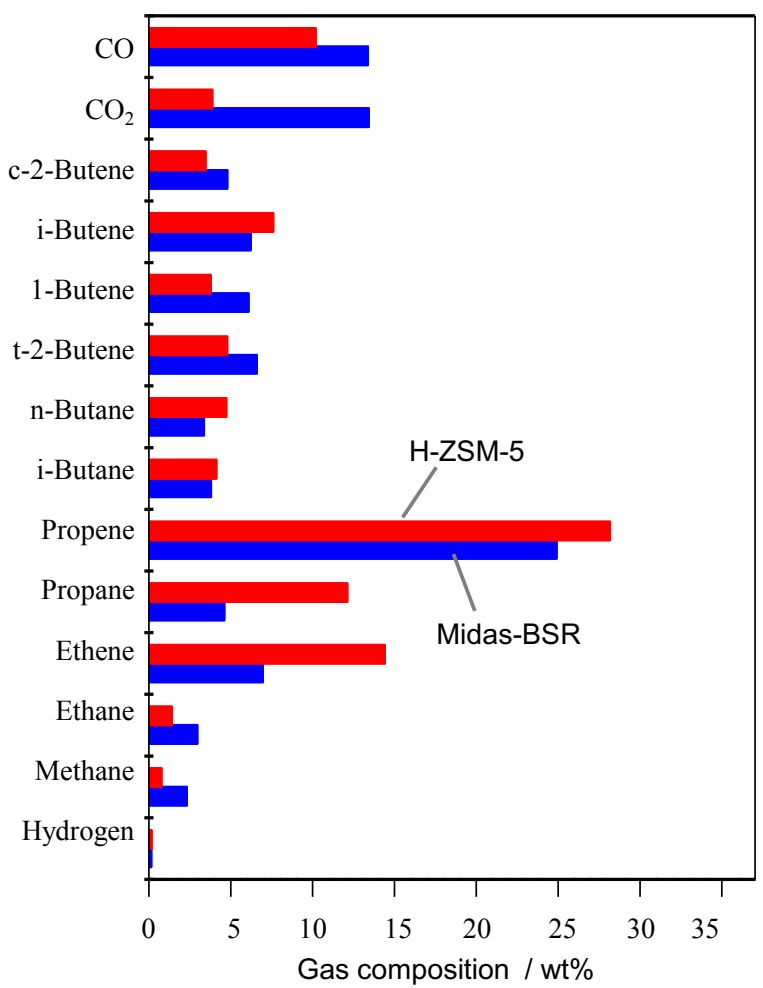

Figure 2. Gas composition in the catalytic cracking of WCO at $550{ }^{\circ} \mathrm{C}$ and a CTO ratio of $0.4 \mathrm{~g} / \mathrm{g}$

For a better understanding of the effect of catalyst characteristics, the gas and gasoline compositions have been examined. From Figure 2, it can be seen that H-ZSM-5 appears more selective toward propene and ethene, but less selective toward $\mathrm{C} 4$ olefins compared to FCC catalyst. It has been reported that in the medium pore zeolite H-ZSM-5 (pore mouths diameter of 0.52-0.56 nm) only monomolecular cracking reactions are operative, resulting in mainly propene and ethene (den Hollander, 2002). In the large pore zeolite Y (pore-mouth diameter of $0.74 \mathrm{~nm}$ ) of FCC catalyst, bimolecular cracking reactions occur along with monomolecular cracking reactions, leading to more $\mathrm{C} 4$ olefins.

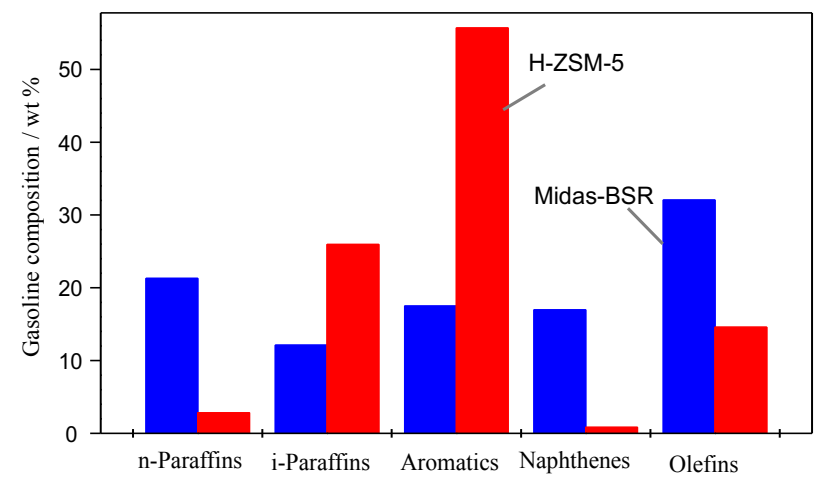

Figure 3. Gasoline composition in the catalytic cracking of $\mathrm{WCO}$ at $550^{\circ} \mathrm{C}$ and a CTO ratio of $0.4 \mathrm{~g} / \mathrm{g}$

The influence of catalyst characteristics on the gasoline composition is shown in Figure 3. Although both the catalysts produced comparable fractions of gasoline, the significant difference in the gasoline components can be observed. H-ZSM-5 yields predominantly gasoline-range aromatics $(55.7 \%)$ and i-paraffins $(25.9 \%)$ while FCC catalyst shows a higher concentration of gasoline-range olefins $(32.0 \%)$ and n-paraffins $(21 \%)$. This indicates that the medium pore size of H-ZSM-5 has promoted the aromatization process, which is in line with the previous works (Chen et al., 2010; Twaiq et al., 1999). The presence of aromatics might increase the octane number of gasoline, but their high concentrations in liquid fuels are not desirable when considering environmental aspects.

\section{Conclusions}

We have shown that the catalyst characteristics have great influence on the product distribution in the cracking of triglyceride based biomass under FCC conditions. The number of acid sites determines, to certain extent, the degradation degree of triglyceride molecules. The higher density of acid sites, the deeper the cracking of triglycerides, and consequently, and ligher and more valuable products have been produced. Under FCC conditions, medium pore zeolite H-ZSM-5 is very selective toward the formation of gasoline-range aromatics and light olefins (particularly propene and ethene) while large pore zeolite Y based FCC catalyst facilitates the formation of gasoline-range and $\mathrm{C} 4$ olefins. These findings might stimulate interest for future works on the rational design of catalysts for the production of renewable gasoline and light olefins by processing of triglyceride based feedstock in standard FCC units.

\section{Acknowledgements}

The authors would like to thank Dr. Nguyen Anh Duc and Mr. Phan Minh Quoc Binh for the permission to access the SCT-MAT facility. Vu Xuan Hoan would like to thank VIED and LIKAT for financial support.

\section{References}

[1] Al-Sabawi, M., Chen, J., Ng, S., 2012. Fluid catalytic cracking of biomass-derived oils and their blends with petroleum feedstocks: A review. Energy Fuels 26: 5355-5372.

[2] Chen, D., Tracy, N.I., Crunkleton, D.W., Price, G.L., 2010. Comparison of canola oil conversion over MFI, BEA, and FAU. Appl. Catal. A Gen. 384: 206-212.

[3] Chhetri, A.B, Watts, K.C., Islam, M. R., 2008. Waste cooking oil as an alternate feedstock for biodiesel production. Energies 1: 3-18.

[4] den Hollander, M.A., Wissink, M., Makkee, M., Moulijn, J.A., 2002. Gasoline conversion: reactivity towards cracking with equilibrated FCC and ZSM-5 catalysts. Appl. Catal. A Gen. 223: 85-102.

[5] Dupain, X., Costa, D.J., Schaverien, C.J., Makkee, M., Moulijn, J.A., 2007. Cracking of a rapeseed vegetable oil under realistic FCC conditions. Appl. Catal. B Environ. 72: 44-61. 
[6] Huber, G.W., Corma, A., 2007. Synergies between bio- and oil refineries for the production of fuels from biomass. Angew. Chem. Int. Ed. 46: 71847201 .

[7] Katikaneni, S.P.R., Adjaye, J.D., Idem, R.O., Bakhshi, N.N., 1996. Catalytic conversion of canola oil over potassium-impregnated HZSM-5 catalysts: $\mathrm{C}_{2}$ $\mathrm{C}_{4}$ olefin production and model reaction studies. Ind. Eng. Chem. Res. 35: 3332-3346.

[8] Maher, K.D., Bressler, D.C., 2007. Pyrolysis of triglyceride materials for the production of renewa- ble fuels and chemicals. Bioresoure Technol. 98: 2351-2368.

[9] Melero, J.A., Iglesias, J., Garcia, A., 2012. Biomass as renewable feedstock in standard refinery units. Feasibility, opportunities and challenges. Energy Environ. Sci. 5: 7393-7420.

[10] Twaiq, F.A., Zabidi, N.A.M., Bhatia, S., 1999. Catalytic conversion of palm oil to hydrocarbons: performance of various zeolite catalysts. Ind. Eng. Chem. Res. 38, 3230-3237. 